\title{
Gray Mold of Grafted Cactus Caused by Botrytis cinerea in Korea
}

\author{
Sooil Bae, Sang Gyu Kim and Young Ho Kim* \\ Department of Agricultural Biotechnology, Seoul National University, Seoul 191-521, Korea \\ (Received on February 16, 2011; Revised on May 13, 2011; Accepted on May 19, 2011)
}

Grafted cactus, produced by grafting two different cactus species including photosynthetic stocks (mostly Hylocereus trigonus) and non-photosynthetic scions (usually Gymnocalycium mihanovichii or Chamaecereus silvestrii), is one of the most popular exporting ornamental plants, comprising about $70 \%$ of the world trading market (Song et al., 2009a, 2009b). Since the grated cactus is cultivated in greenhouses with warm temperature and high humidity during the whole growing season, several diseases especially caused by fungi such as Bipolaris cactivora, Colletotrichum gloeosporioides (anamorph of Glomerella cingulata), Fusarium oxysporum, and Alternaria alternata are frequently found in the cactus farms in Korea (Chang et al., 1998; Choi et al., 2010; Hyun et al., 1998; Kim et al., 2000).

A stem disease of G. mihanovichii caused by a fungus was observed in 2010 in several greenhouses especially with high humidity at Goyang, Gyeonggi province, the major cactus-growing area in Korea. Its occurrence was not prevalent and found mostly in mature (old) cactus plants. Characteristic symptoms were initial black or brown spots that were enlarged with time to become shrunken or water-soaked black lesions at advanced infection stages (Fig. 1A \& B). Isolation of fungi and bacteria from the rotten stems of $G$. mihanovichii was tried to, but it was fail the isolation of the previously known fungal and bacterial pathogens such as $B$. cactivora, $C$. gloeosporioides, $F$. oxysporum, A alternata, and Pectobacterium carotivorum (Kim et al., 2007) except seven fungal isolates with identical morphological characteristics. The mycological characteristics of the fungal isolates were as follows. The fungus formed grayish brown colonies with the production of abundant flat or irregular black sclerotia on potato-dextrose agar(PDA) (Fig. 1C). Conidiophores were upright, tall and slender, $8.0-31.0 \mu \mathrm{m}$ in width, determinate, hyaline or grayish, branched irregularly in upper portions, bearing clusters of conidia simultaneously on short denticles (Fig. 1D). Conidia were one celled, colorless or pale brown, mostly ellipsoid or ovoid, and 8.5-12.3 ×6.3-11.2 $\mu \mathrm{m}$ in size (Fig. 1E). These morphological characteristics of the present isolates coincide with those of Botrytis cinerea described by Ellis and Waller (1974).

To confirm the identification of the fungus, the partial internal transcribed space (ITS) region of rDNA from the present isolate was amplified using the primers ITS 1 and ITS 4 as described by White et al. (1990) and sequenced. The resulting sequences were compared

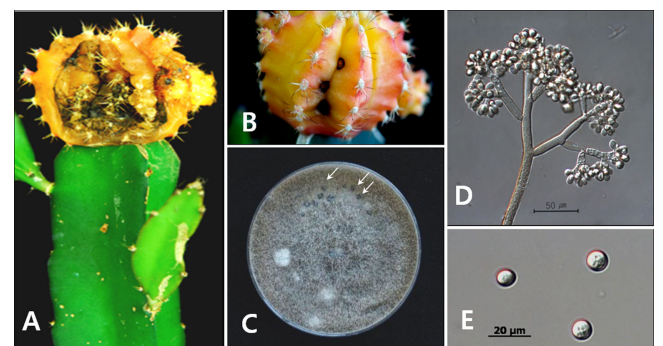

Fig. 1. Gray mold on a mature grafted cactus (Gymnocalycium mihanovichii) caused by Botrytis cineria, showing the symptoms on the stems with natural infection (A) and induced by artificial inoculation (B), the fungal colony with black sclerotia (arrows) grown for 30 days on PDA (C), and light microscopy of the fungal conidiophores $(\mathrm{D}$, bar $10 \mu \mathrm{m})$ and conidia $(\mathrm{E}, \operatorname{bar} 20 \mu \mathrm{m})(\mathrm{D}, \mathrm{E})$ to the GenBank database using the NCBI BLAST search program. A total of 798 base sequences determined from the ITS DNA were $100 \%$ identical to those of several Botryotinia fuckeliana (teleomorph of Botrytis cineria) strains of NCBI accession nos. HM849615.1,HM849047.1,HQ166517.1, andFN812726.1, indicating the causal fungus was confirmed to be $B$. cinerea .

For pathogenicity test, one-year-old stems of $G$. mihanovichii were inoculated with spore suspension $\left(1 \times 10^{6} \mathrm{spores} / \mathrm{ml}\right)$ of the fungal isolate by spray on a wound of ca. $0.5 \mathrm{~mm}$ (diameter) $\times 5 \mathrm{~mm}$ (depth) made with a syringe needle, and were incubated under saturated humid condition at room temperature for one day, and placed at $25^{\circ} \mathrm{C}$ and $\mathrm{RH} 40 \%$ in a growth chamber. Initial symptoms of dark brown lesions (identical to those found in the cactus greenhouses) were developed around wounding sites and enlarged with time (Fig. 1B). The same fungus was re-isolated from the diseased area to fulfill the Koch's postulates. Therefore, the cactus disease was caused by $B$. cinerea whose identity was confirmed on the basis of its morphological and molecular characteristics. This is the first report of gray mold by $B$. cineria in the grafted cactus. As found no other fungal and bacterial pathogens previous known to occur in $G$. mihanovichii, especially $B$. cactivora causing the similar cactus stem rot, $B$. cinerea should be the primary causal agent for the disease development.

\section{Acknowledgement}

This study was supported financially by Technology Development Program for Agriculture and Forestry, Ministry for Food, Agriculture, Forestry and Fisheries, Republic of Korea.

\section{References}

Chang, M., Hyun, I. H. and Lee, Y. H. 1998. Bipolaris stem rot of cactus caused by Bipolaris cactivora (Petrak) Alcorn. Korean J. Plant Pathol. 14:661-663.

Choi, M.-O., Kim, S. G., Hyun, I.-H., Kim, J. H., Cho, C.-H., Park, M. S. and Kim, Y. H. 2010. First report of black spot caused by Alternaria alternata on grafted cactus. Plant Pathol. J. 26:80-82.

Ellis, M. B. and Waller, J. M. 1974. CMI descriptions of pathogenic fungi and bacteria. No. 431. Commonwealth Mycological Institute, Kew, Surrey, England.

Hyun, I. H., Lee, S. D., Hwang, B. C., Ko, K. I., Chung, H. S. and Kim, B. K. 2001. Occurrence of stem rot caused by Bipolaris cactivora on different species of cactus and its pathogenicity. Res. Plant Dis. 7:56-59.

Kim, J. H., Joen, Y. H., Kim, S. G. and Kim, Y. H. 2007. First report on bacterial soft rot of graft-cactus Chamaecereus silvestrii caused by Pectobacterium carotovorum subsp. carotovorum in Korea. Plant Pathol. J. 23:314-317.

Kim, Y. H., Jun, O. K., Sung, M. J., Shin, J. S., Kim, J. H. and Jeoung, M. I. 2000. Occurrence of Colletotrichm stem rot caused by Glomerella cingulata on graft-cactus in Korea. Plant Pathol. J. 16:242-245.

Song, C. Y., Ahn, D. H., Cho, C. H., Chung, J. W. and Nam, S. Y. 2009a. Exporting promotion strategy of grafted cacti. Flower Res. J. 17:67-73.

Song, C. Y., Ahn, D. H., Kim, Y. S., Park, I. T. and Cho, C. H. 2009 b. Export market trends of grafted cacti. Flower Res. J. 17:62-66.

White, T. J., Bruns, T., Lee, S. and Taylor, J. 1990. Amplification and direct sequencing of fungal ribosomal RNA genes for phylogenetics. In: PCR Protocols: A guide to methods and applications, ed. by M. A. Innis, D. H. Gelfand, J. J. Sninsky, and T. J. White, pp. 315-322. Academic Press, Inc., New York.

*Corresponding author (yhokim@snu.ac.kr) 